\title{
Sensory Performance, Proximate and Antioxidant Activity of Tea from Composite Formulation of Cymbopogon citratus, Lippia multiflora and Ganoderma lucidum
}

\author{
Courage Sedem Dzah \\ Department of Hospitality and Tourism Management, Faculty of Applied Sciences and Technology, Ho Polytechnic, Ghana
}

\section{Email address:}

dzahcourage@yahoo.com

To cite this article:

Courage Sedem Dzah. Sensory Performance, Proximate and Antioxidant Activity of Tea from Composite Formulation of Cymbopogon citratus, Lippia multiflora and Ganoderma lucidum. Journal of Food and Nutrition Sciences. Vol. 3, No. 3, 2015, pp. 131-138. doi: $10.11648 /$ j.jfns.20150303.19

\begin{abstract}
Commercially produced herbal green teas consumed in Ghana are mostly those imported into the country. However, there are many plants such as "Srenunum" (Lippia multiflora) and lemongrass (Cymbopogon citratus), that are used by Ghanaians to brew herbal tea. The objectives of this study were to develop a tea product from the aforementioned herbs and "reishi" (Ganoderma lucidum), a medicinal mushroom. Three formulations (A, B and C) were produced according to the respective percentages (50:30:20, 30:20:50 and 20:50:30 for G. lucidum: L. multiflora: C. citratus). Formulation A came out as the most liked tea through an affective test ( 7 point hedonic scale) which was then compared to a known control (Liptonyellow label) by chemical, proximate, antioxidant activity determination and sensory evaluation. The two tea samples (Tea A and Lipton) differed significantly with respect to aroma, colour, after taste and overall acceptability ( $p<0.05)$. Tea A had significantly higher values for proteins, crude fibre and ash contents than Lipton in terms of their proximate compositions whereas Lipton contained higher levels of moisture and lipids $(\mathrm{P}<0.05)$. For increasing concentrations of tea samples $(10$, 15, 20,30,50 $\mathrm{L}$ ) used in antioxidant activity determination, tea A recorded between 59.07 and $88.91 \mathrm{mgTE} / \mathrm{g}$, significantly higher than for Lipton (between 22.81 and 34.45mgTE/g) $(\mathrm{P}<0.05)$. Given the high performance of Tea A, G. lucidum, L. multiflora and $C$. citratus can be successfully used to produce tea of equally good quality to encourage local consumption of indigenous herbs as well as reduce tea imports.
\end{abstract}

Keywords: Cymbopogon citratus, Herbal Tea, Lippia multiflora, Ganoderma lucidum

\section{Introduction}

Tea is a common beverage and most consumed after water worldwide and can be classified into three types known as green (unfermented), oolong (partially fermented) and black (fermented) teas [1]. There are many types of tea products, one of such is the common brand, Lipton among others which are imported and marketed in Ghana. As a developing country with a food security and economic growth agenda, Ghana's indigenous herbs which are already being used for medicinal and refreshment purposes and which form part of Ghanaian culture should be utilized in tea production [2-4]. Also, in order to reduce the nation's expenditure on tea importation, other herbs such as the lemon grass (Cymbopogon citratus) and an indigenous plant called "Srenunum" in the Ghanaian Twi dialect (Lippia multiflora) should be valorized to enhance their use as herbal teas in Ghana.
Beside economic benefits earlier mentioned, tea from $C$. citratus leaves is used for its analgesic, antispasmodic, antiinflammatory, antipyretic, diuretic and sedative medical effects and as well in the treatment of digestive disorders, fevers, menstrual disorder, rheumatism and other joint pains [5-8]. A meta-analysis of a number of population studies suggests that consumption of green and black tea beverages may bring positive health effects due to the high levels of flavonoids and antioxidants [9]. Another study showed that substantial number of studies with green and black tea demonstrated a significant increase in plasma antioxidant capacity in humans approximately 1 hour after consumption of moderate amounts of tea (1-6 cups/day) leading to reduced oxidative damage [10].

Lippia multiflora is one of the about 240 plant Lippia species which are extremely plentiful, aromatic and occur mostly in the tropics of America and Africa [11,12]. Many 
species are widely used for their medicinal properties and to season foods. Lippia species are also used traditionally for the treatment of a variety of ailments such as gastrointestinal, respiratory complaints and for relaxation and sedation $[3,12]$. Other studies also linked the use of Lippia multiflora to the treatment of blood pressure, malaria, diarrhea and mild hypertension $[2,3,13]$.

The mushroom, Ganoderma lucidum, commonly referred to as "Lingzhi" or "reishi" has been used in Asia, especially in China for health promotion and longevity for centuries. This mushroom has recently been studied and known to have numerous pharmacological effects including immunomodulating, anti-inflammatory, anti-cancer, anti-diabetic, anti-oxidative and radical scavenging, and anti-aging effects among others [14-17]. Another study conducted earlier also confirmed that $G$. lucidum extracts possess anti-proliferative effects on many cancers, such as acute myelogenous leukaemia [18].

Considering literature support on the benefits of $L$. multiflora, C. citratus and G. lucidum, and the fact that they have all been used traditionally for quite long, it was not out of place to consider combining the three to develop a unique tea product. This study therefore sought to develop a unique tea product from these three healthful ingredients and compare with a top, known and common brand, Lipton for acceptability, chemical, proximate composition and antioxidant activity.

\section{Material and Methods}

\subsection{Materials}

L. multiflora and C. citratus were collected from Juapong in the Volta region of Ghana while G. lucidum was obtained from the botanical garden of Kwame Nkrumah University of Science and Technology, Ghana and identified at the Center for Scientific and Industrial Research-Food Research Institute (CSIR-FRI), Accra. L. multiflora and C. citratus were cleaned and dried in the solar dryer for 48 hours and $G$. lucidum for 72 hours. G. lucidum was dried for 72 hours because of its hard, woody basidiocarp which slowed the rate of drying. The materials were then separately milled into powder and three (3) out of nine (9) formulations selected ( $\mathrm{A}=50: 30: 20, \mathrm{~B}=30: 20: 50$ and $\mathrm{C}=20: 50: 30$ for $\%$ G. Lucidum L. multiflora: C. citratus). The various formulations were packed in air tight plastic containers and stored at $-20^{\circ} \mathrm{C}$ for further analyses.

\subsection{Methods}

\subsubsection{Proximate Analyses}

Proximate analyses of the tea formulation A (selected through an affective test as most accepted) and Lipton were done using the method of Association of Official Analytical Chemists [19].

\subsubsection{Moisture Content Determination}

Petri dishes were selected, cleaned and labeled. The dishes were dried in a hot air oven at $105^{\circ} \mathrm{C}$ for about 30 minutes and cooled in an air-tight desiccator. The dishes were then weighed after being removed from the desiccator using a calibrated digital analytical balance and their various weights were recorded. $2 \mathrm{~g}$ of each sample was weighed into the labeled pre-weighed Petri dishes and weighed again. They were immediately transferred into an air oven pre-set at $105^{\circ} \mathrm{C}$ to dry. Samples in crucibles had their weights measured severally until they obtained constant weights as final values. The difference in initial and final weights indicated moisture contents of tea samples.

\subsubsection{Lipids Content Determination}

$1.0 \mathrm{~g}$ each of the samples was weighed into a pre-weighed thimble. $150 \mathrm{ml}$ pet ether was measured into a $250 \mathrm{ml}$ conical flask using the measuring cylinder. The samples were then extracted under reflux using a soxhlet extractor fitted with thimble containing samples. The extraction was stopped after eight (8) hours and the thimbles with contents were removed, dried in an oven at $105^{\circ} \mathrm{C}$ for two hours and weighed with an analytical balance.

\subsubsection{Ash Content Determination}

Porcelain crucibles were selected ( 3 for each sample), cleaned and labeled. The crucibles were dried in the hot air oven at $105^{\circ} \mathrm{C}$ for about 30 minutes and placed in a desiccator to cool. The initial weights of the cooled crucibles were recorded. $2.0 \mathrm{~g}$ of each sample was weighed into each of the crucibles and placed in a muffle furnace (Gallenkamp model) to carbonize at $600^{\circ} \mathrm{C}$ for 2 hours till the samples had a cotton wool like texture. The crucibles with the ash were removed and kept in a desiccator to cool. They were reweighed and the percentage ash was calculated.

\subsubsection{Protein Content Determination}

One gram $(1.0 \mathrm{~g})$ each of the samples (tea formulation A and Lipton) was weighed into the kjeldahl flask. $1.0 \mathrm{~g}$ of $\mathrm{K}_{2} \mathrm{SO}_{4}$ and $0.1 \mathrm{~g} \mathrm{Ca}_{2} \mathrm{SO}_{4}$ were added into the flask and mixed with $20 \mathrm{ml}$ of $\mathrm{H}_{2} \mathrm{SO}_{4}$ after which the flask was placed on the kjeldahl digestion heating mantle in a slanting position in a fume chamber. The process was monitored until a color change which was from black to bluish-green was observed. The reaction was then stopped and digests removed and cooled. They were then topped with water and made up to $200 \mathrm{ml}$ mark on ice. $50 \mathrm{ml}$ of aliquot of each digest was poured into a distillation flask and carefully layered with $50 \mathrm{ml}$ of $\mathrm{NaOH}$. The solution was then distilled into a receiving flask containing $50 \mathrm{ml}$ of $0.1 \mathrm{~N} \mathrm{H}_{2} \mathrm{SO}_{4}$ with two drops of methyl red as an indicator. Distillation was stopped by removing the solution in the receiving flask immediately before putting of hot mantle to avoid drop in pressure. The distillate was titrated with $0.1 \mathrm{M} \mathrm{NaOH}$ and percentage nitrogen calculated as protein content.

\subsubsection{Crude Fibre Content Determination}

This is organic residue which remains after the materials have been treated with standardized conditions with light petroleum, boiling dilute $\mathrm{H}_{2} \mathrm{SO}_{4}$, boiling dilute $\mathrm{NaOH}$ 
solution, dilute $\mathrm{HCl}$, alcohol and ether. The crude fibre consists largely of cellulose together with a little lignin and it can be extrapolated as 100-(\% Moisture+\% Ash+\% Lipid $+\%$ Protein).

\subsection{Chemical Analysis}

\subsection{1. pH Determination}

The $\mathrm{pH}$ of tea samples (tea A and Lipton) were read suing a digital pH meter (model HI 2211, Hanna instruments, USA) in triplicates by dipping electrode in tea samples and allowing readings to stabilise.

\subsubsection{Water Extractives Determination}

Beside proximate analysis, the amount of solids that can be extracted from tea samples when brewed (water extractives) was determined for both tea samples. $2.0 \mathrm{~g}$ of each sample was weighed into round bottom flasks and fitted to reflux condensers. $100 \mathrm{ml}$ distilled water was added to each of them and were boiled for one hour and filtered using Whattman filter paper. The filtrates were poured into beakers and evaporated over steam on a water bath until the contents on the beakers reduced by about $95 \%$. At this time, the beakers were removed into a hot air oven to dry. The beakers containing the dry sample solids were removed after drying and placed in a desiccator to cool. They were then reweighed and their respective weights recorded. The percentage total solids were calculated for the two tea samples.

\subsubsection{Sensory Evaluation}

The most accepted of the three tea formulations (A) was sensorially evaluated against Lipton tea brand. A total of thirty fife (35) untrained panellists were randomly recruited from among students in The Kwame Nkrumah University of Science and Technology, Kumasi. The criteria with which sensory panellists were selected were their familiarity with tea quality parameters, were in good health and willing to participate in the exercise.

The sensory room was well lit and air conditioned to ensure comfort of panellists as well as prevent exterior distractions. Two sets of sensory evaluation were organized; the first for the three tea formulations A, B and C in order to select the most preferred, and the second to evaluate the acceptance of the most preferred against a known brand (Lipton). In each case, the same approach was used. For the second part of the sensory evaluation, panellists were then asked to evaluate the 2 randomly coded samples (tea A and Lipton) on a 7 - point hedonic scale (1 dislike very much, 2 dislike moderately, 3 dislike slightly, 4 neither like nor dislike, 5 like slightly, 6 like moderately, 7 like very much) in an affective sensory evaluation of parameters such as aroma, colour, taste, after taste, astringency and overall acceptability. Panellists had no previous information about samples tested in order to avoid bias.

\subsection{Antioxidant Activity Determination}

Prior to antioxidant activity determinations for tea samples (formulation A and Lipton), hydrophilic extraction of antioxidants was done for each tea sample [20]. The Trolox Equivalent Antioxidant Capacity (TEAC) assay was used to determine antioxidant activity. Buffer solutions were prepared from $0.1 \mathrm{M} \mathrm{NaOH}_{2} \mathrm{PO}_{4} \mathrm{x}_{2} \mathrm{H}_{2} \mathrm{O}(\mathrm{N}=2.9, \mathrm{MW}=120)$, $0.1 \mathrm{M} \mathrm{Na}_{2} \mathrm{HPO}_{4}(\mathrm{~N}=2.6, \mathrm{MW}=177.99)$ and $\mathrm{NaCl}$. Reaction solution was prepared from $0.5335 \mathrm{~g}$ 2,2'-azinobis-(3ethylbenzothiazoline-6-sulfonic acid) (ABTS) and $0.0339 \mathrm{~g}$ 2,2'-azobis(2-amidopropane) (ABAP) each in $50 \mathrm{~mL}$ of buffer solution. Reaction mixture was incubated at $65^{\circ} \mathrm{C}$ for 30 minutes to enhance the formation of ABTS radicals (ABTS*) which gave a greenish solution of a \pm 0.4 absorbance at $734 \mathrm{~nm}$ against a blank buffer solution. The reaction solution was then centrifuged at $20000 \mathrm{rpm}$ for 15 minutes at $20^{\circ} \mathrm{C}$ and supernatants used immediately. Hydrophilic antioxidant extracts were then diluted by a factor of $5(200 \mu \mathrm{L}$ sample: $800 \mu \mathrm{L}$ buffer solution) before use. $10,15,20,30$ and $50 \mu \mathrm{L}$ samples were respectively added to 290, 285, 280, 270 and $250 \mu \mathrm{L}$ reaction solutions in spectrophotometry plate wells in triplicates and incubated at $37^{\circ} \mathrm{C}$ for 6 minutes and absorbance read at $734 \mathrm{~nm}$ against blank (buffer solution). Reduction in greenish colour of reaction mixture represents radical inhibition by antioxidants in samples analyzed.

\subsection{Data Analysis}

Data were analysed by analyses of variance (ANOVA) using SPSS (version 22.0) with a 95\% confidence interval. Significance was set at $\mathrm{P}<0.05$. Results were presented in tables and figures and interpreted accordingly.

\section{Results and Discussion}

\subsection{Chemical Analysis}

Tea A was slightly more acidic than the control (Lipton) (Table 1). Concerning the amount of dissolved solids in infused tea samples, Tea A recorded significantly higher value for water extractives (36.53) than Lipton (19.77) (Table 1). This difference was partly due to the smaller granular size of tea contents as Tea A contained more tiny granules than Lipton, which gave it a larger surface area, enabling faster and easier dissolution in hot water [21]. This difference was also explained by the inherent differences in total soluble solids contents of the sample components. G. lucidum was found to contain high levels $(82 \%)$ of water-soluble polysaccharides [22]. Similar assertion can be made for $L$. multiflora with high soluble solids [23].

\subsection{Proximate Analyses}

Tea A had significantly higher values than Lipton in terms of their proximate compositions with respect to proteins, crude fibre and ash $(\mathrm{P}<0.05)$ whereas Lipton contained significantly higher levels of moisture and lipids (Table 2). An earlier study showed proximate results for $C$. citratus to be $4.56,64.00$ and $20.00 \%$ for crude protein, crude fibre and ash respectively [6]. Similar analysis in other studies showed results for crude protein, crude fibre and ash contents for $G$. lucidum (26.40, 51.50 and 6.50) and L. multiflora (12.95, 
80.00 and $10.25 \%$ ) which did not differ much from those obtained in this study (Table 2) [24,25]. These findings compare fairly with values obtained for protein, crude fibre and ash contents of tea A. Although protein content was relatively high for Tea A $(9.02 \%)$ (Table 2$)$, results only showed protein contents of raw tea but did not determine how much protein is available in infused tea. This gap will be addressed in future studies as a study by the American Heart Association showed that high protein drinks may pose health risks to certain individuals beside the fact that they are helpful in weight loss and muscle building [26]. The high protein content was also explained by the $30 \%$ G. lucidum (mushroom) in the formulation.

\subsection{Sensory Evaluation of Tea Samples}

The need for sensory evaluation of formulated tea sample is crucial and more so when compared with a known brand like Lipton. And this is a commonly accepted approach adopted when developing new food products [27]. A 7-point hedonic scale (1 dislike very much - 4 neither like nor dislike - 7 like very much) was used to assess sensory attributes such as aroma, colour, taste, after taste, astringency and overall acceptability by means of an affective test. Mean scores were calculated for each attribute and a summary presented (Tables 3). Table 3 depicts results for the three different tea formulations (A, B and $\mathrm{C}$ ) with sample $\mathrm{A}$ being ranked best with a mean overall score of 5.44 (like slightly) higher that samples B (4.98) and C (4.04). There were significant differences observed between tea formulations regarding all sensory attributes (Table 3$)(\mathrm{P}<0.05)$. Best tea sample (Tea A) was compared sensorially with a known control, Lipton and results tabulated (Table 4).

Mean scores for aroma, colour, after taste and overall acceptability showed significant differences between tea A and the known control brand, Lipton $(\mathrm{P}<0.05)$ (Table 4). No significant differences were however observed between samples for taste and astringency. Tea A which consists of 50\% C. citratus, $30 \%$ G. lucidum and $20 \%$ L. multiflora significantly out-performed the control (Lipton) regarding the attributes aroma and overall acceptability $(\mathrm{P}<0.05)$ (Table 4$)$. Nonetheless, panellists rated the control (Lipton) significantly higher in colour and aftertaste than tea A $(\mathrm{P}<$ $0.05)$.

\section{Effects of Formulation Components on Sensory Attributes of Tea A}

\subsection{Aroma}

The mean scores for aroma of tea samples were 5.63 (like slightly) and 4.00 (neither like nor dislike) respectively for tea A and Lipton (Table 4). Given that the infused tea samples contained no additives, it was believed that their aroma were coming only from the samples themselves. Serving temperature was held constant to avoid bias as temperature is known to influence aroma perception in foods
[28]. Tea A which contained 50\% C. citratus, $30 \%$ G. lucidum and $20 \%$ L. multiflora had a significantly higher acceptability for aroma than Lipton. It was realized from preliminary sensory test for three (3) tea formulations that those with higher percentages of $C$. citratus had higher scores for aroma (Table 3). Other studies also support this point that pure lemongrass tea's acceptability was strongly linked to its citral aroma $[29,30]$.

\subsection{Colour}

For colour, the control sample, Lipton scored significantly higher than tea A as shown in Table 4. Although $C$. citratus had excellent colour attribute due to its light and clear green colour, combining it with L. multiflora and G. lucidum impacted overall colour of the formulation [29]. When brewed separately, L. multiflora and C. citratus had light green colour with the exception of $G$. lucidum which had a dark brown colour. A mixture of the three components resulted in an infusion with a hazy light brown colour against a clear, bright brown colour of Lipton. It was not surprising that the control tea sample (Lipton) scored higher on colour as clearness of infusions is a more preferred attribute that enhances colour brightness than haziness in tea [4].

\subsection{Taste}

Mean scores showed no significant difference between tea samples for taste (Table 4). It was observed that the control tea (Lipton) scored slightly higher (5.03) than tea A (4.89) for taste and this was best explained by the bitter taste contributed by $G$. lucidum [31,32]. This bitter taste from $G$. lucidum masked the pleasant citral tastes of $L$. multiflora and C. citratus significantly thereby influencing overall taste of tea A.

\subsection{After Taste}

The aftertaste of foods including tea describes the lasting impression of the food after consumption and seems to mask acceptable attributes such as taste since it is most often perceived last. As the taste of new products and functional foods such as teas is a crucial determinant of acceptance, aftertaste plays a similar role [33]. Unlike $C$. citratus and $L$. multiflora, $G$. lucidum has a bitter aftertaste which however does not linger for long. This was the best explanation for the low score for tea A regarding aftertaste. It is therefore understandable that while $C$. citratus and L. multiflora are patronized for their medicinal and refreshing attributes, $G$. lucidum is mostly used as medicinal and not for refreshment $[6,7,12,14]$.

\subsection{Astringency}

Lemongrass ( $C$. citratus) has been found to be astringent $[34,35]$. Another study also confirmed that the young leaves of L. multiflora are especially astringent [36]. However, neither tea A nor Lipton was preferred for astringency as they both had scores around 4 (neither liked nor disliked) as shown in Table 4. 


\subsection{Overall Acceptability}

For overall acceptability, tea A scored significantly higher than the control (Lipton). Regardless of the fact that tea A scored lower for taste and aftertaste, its strong citrus aroma due to the high percentage of lemongrass $(C$. citratus) $(50 \%)$ in the formulation explained its preference to Lipton (Table $3)$.

\section{Antioxidant Activity Determination}

Antioxidant capacity assessment of tea samples by TEAC method showed that all the sample extracts were able to quench the ABTS* radical (Figure 2). However, tea A recorded significantly higher TEAC values ranging between 59.07 and $88.91 \mathrm{mgTE} / \mathrm{g}$ whereas control tea sample (Lipton) had values ranging from 22.81 and $34.45 \mathrm{mgTE} / \mathrm{g}$ of sample (Figure 2). The relatively higher antioxidant activity of tea A can be justified by its high content $(50 \%)$ of C. citratus which was confirmed to have high antioxidant activity [6]. Other studies also demonstrated thatthe antioxidant activity of 1 gof $L$. multiflora leaf is equivalent to 2.7-12.4g of Trolox, indicating its potential as a strong antioxidant [37]. Similar comments could be passed about G. lucidum as results clearly indicated that it is effective as an antioxidant against free radical mediated diseases [38].

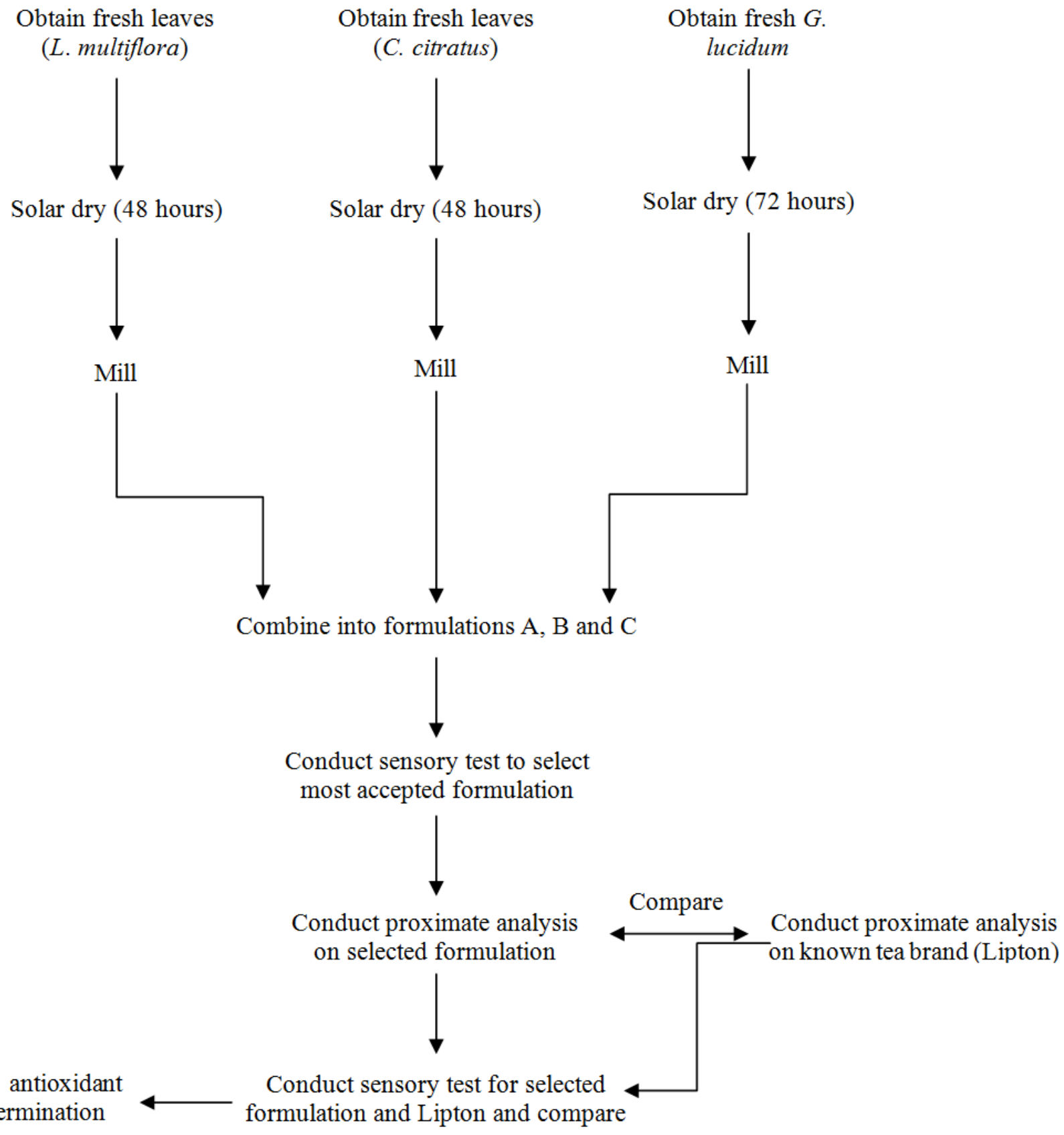

Conduct antioxidant activity determination
Obtain fresh leaves

Mill btain fresh $G$. cidum

Solar dry (72 hours) 


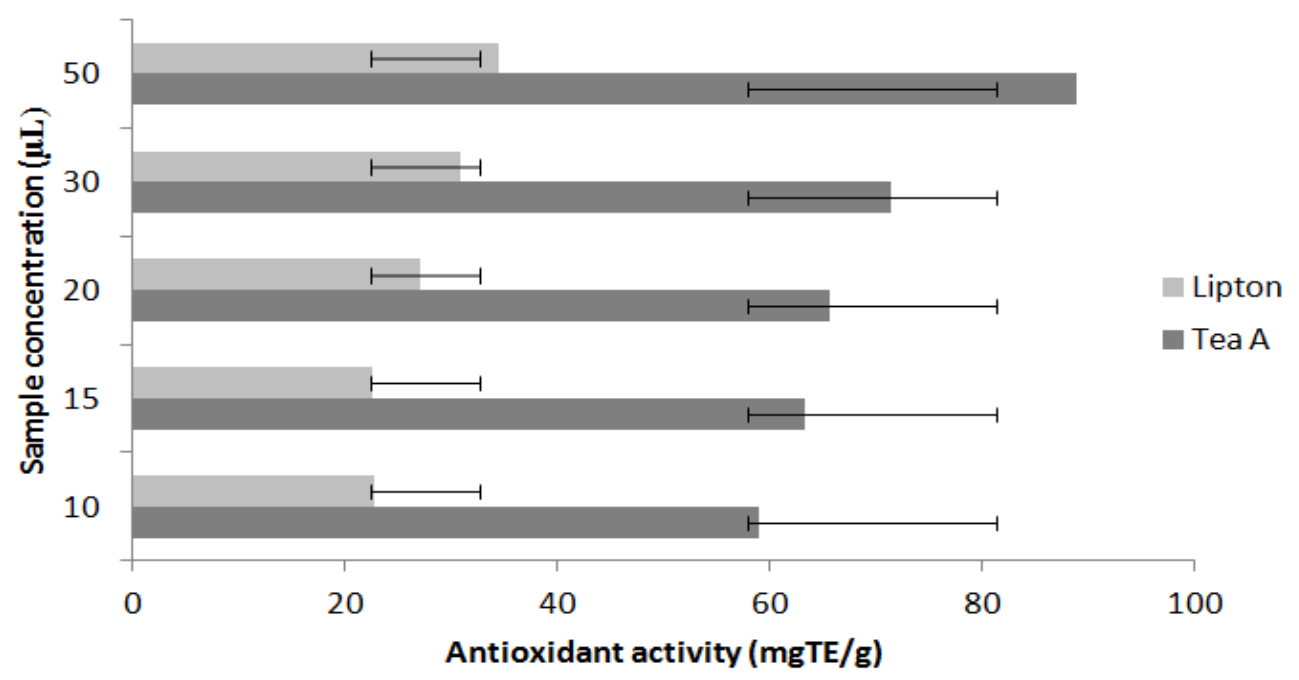

Figure 2. Antioxidant activity for tea samples. Tea A contained $50 \%$ C. citratus, $30 \%$ G. lucidum and $20 \%$ L. multiflora. Lipton was control sample. Error bars represent standard deviations. Values are means of three readings (triplicates).

Table 1. $p H$ and water extractives values for tea samples.

\begin{tabular}{lll}
\hline Sample & $\mathbf{p H}( \pm$ SD) & Water extractives $( \pm$ SD) \\
\hline Tea A* & $4.65( \pm 0.03)$ & $36.53( \pm 0.13)$ \\
Lipton & $5.07( \pm 0.00)$ & $19.77( \pm 0.06)$ \\
\hline
\end{tabular}

* depicts formulated tea with $50 \%$ C. citratus: $30 \%$ G. lucidum: $20 \%$ L. multiflora. Values are means of triplicate readings.

Table 2. Proximate analysis of formulated tea (A) and Lipton.

\begin{tabular}{llllll}
\hline Sample & Moisture $(\% \pm$ SD) & Proteins $(\% \pm$ SD) & Crude fibre $(\% \pm$ SD) & Lipids $(\% \pm$ SD) & Ash(\% \pm SD) \\
\hline Tea A* & $7.15( \pm 0.17) \mathrm{a}$ & $9.02( \pm 0.00) \mathrm{a}$ & $77.06( \pm 0.33) \mathrm{a}$ & $0.07( \pm 0.02) \mathrm{a}$ & $5.83( \pm 0.36) \mathrm{a}$ \\
Lipton & $12.05( \pm 0.04) \mathrm{b}$ & $0.08( \pm 0.00) \mathrm{b}$ & $50.11( \pm 0.27) \mathrm{b}$ & $2.37( \pm 0.04) \mathrm{b}$ & $4.99( \pm 0.40) \mathrm{b}$ \\
\hline
\end{tabular}

* depicts formulated tea with percentages of $50 \%$ C. citratus: $30 \%$ G. Lucidum: $20 \%$ L. multiflora

Table 3. Sensory evaluation for tea formulations.

\begin{tabular}{lllllll}
\hline \multirow{2}{*}{ Sample } & \multicolumn{2}{l}{ Mean score for sensory attributes } & & & \\
\cline { 2 - 7 } & Aroma & Colour & Taste & After taste & Astringency & Overall acceptability \\
\hline A & $6.32( \pm 2.00)^{\mathrm{a}}$ & $5.91( \pm 1.03)^{\mathrm{a}}$ & $5.00( \pm 0.74)^{\mathrm{a}}$ & $4.93( \pm 2.22)^{\mathrm{a}}$ & $4.47( \pm 0.08)^{\mathrm{a}}$ & $6.01( \pm 1.87)^{\mathrm{a}}$ \\
B & $5.11( \pm 1.87)^{\mathrm{b}}$ & $5.77( \pm 1.29)^{\mathrm{a}}$ & $4.28( \pm 1.07)^{\mathrm{b}}$ & $5.15( \pm 1.92)^{\mathrm{a}}$ & $3.92( \pm 1.01)^{\mathrm{b}}$ & $5.66( \pm 2.02)^{\mathrm{b}}$ \\
$\mathrm{C}$ & $4.28( \pm 1.03)^{\mathrm{c}}$ & $3.06( \pm 2.13)^{\mathrm{b}}$ & $4.90( \pm 2.19)^{\mathrm{c}}$ & $3.26( \pm 1.33)^{\mathrm{b}}$ & $4.75( \pm 1.16)^{\mathrm{a}}$ & $4.00( \pm 1.18)^{\mathrm{c}}$ \\
\hline
\end{tabular}

A (50\% C. citratus :30\% G. lucidum: 20\% L. multiflora); B (30\% C. citratus :20\% G. lucidum: 50\% L. multiflora); C (20\% C. citratus :50\% G. lucidum: $30 \%$ L. multiflora).

Table 4. Sensory evaluation of tea samples.

\begin{tabular}{|c|c|c|c|c|c|c|}
\hline \multirow{2}{*}{ Sample } & \multicolumn{6}{|c|}{ Mean scores for sensory attributes } \\
\hline & Aroma & Colour & Taste & After taste & Astringency & Overall acceptability \\
\hline Tea A & $5.63( \pm 1.92)^{\mathrm{a}}$ & $5.43( \pm 1.86)^{\mathrm{a}}$ & $4.89( \pm 2.00)^{\mathrm{a}}$ & $4.15( \pm 1.80)^{\mathrm{a}}$ & $4.02( \pm 1.91)^{\mathrm{a}}$ & $5.31( \pm 1.52)^{\mathrm{a}}$ \\
\hline Lipton & $4.00( \pm 1.02)^{\mathrm{b}}$ & $6.25( \pm 1.91)^{\mathrm{b}}$ & $5.03( \pm 2.21)^{\mathrm{a}}$ & $5.20( \pm 1.94)^{\mathrm{b}}$ & $4.33( \pm 2.26)^{\mathrm{a}}$ & $4.74( \pm 1.78)^{b}$ \\
\hline
\end{tabular}

A $(50 \%$ C. citratus $: 30 \%$ G. lucidum: $20 \%$ L. multiflora). Mean scores with same letters in the same column do not differ significantly (P $>0.05)$. Lipton was the control sample.

\section{Conclusion}

For the development of herbal tea, the formulation consisting of $50 \%$ C. citratus, $30 \%$ G. lucidum and $20 \% \mathrm{~L}$. multiflora was used to produce tea that was better accepted than a known control brand, Lipton-yellow label sensorially. Tea $\mathrm{A}$ as well performed better with significantly higher antioxidant activity than the control tea beside its higher 
protein, ash and fibre contents. Consequently C. citratus, $G$. lucidum and L. multiflora can be used as composite to produce tea of better quality to enhance healthful benefits from their high contents of antioxidants. This will also encourage the consumption of indigenous products and generate employment to many, culminating in economic development as tea imports may also reduce.

\section{References}

[1] Cheng, T.O. 2004. Will green tea be even better than black tea to increase coronary flow velocity reserve? American Journal of Cardiology. 94:12-23.

[2] Ameyaw, Y. 2009. A growth regulator for the propagation of Lippia multiflora Moldenke, a herbal for the management of mild hypertension. Ghana Journal of Medicinal Plants Research. 3(9): 681- 685.

[3] Folashade, K.O. and Omoregie, E.H. 2012. Essential oil of Lippia multiflora Moldenke: A review. Journal of Applied Pharmaceutical Science. 2(1):15-23.

[4] Ekissi, A.C., Konan, A.G., Yao-Kouame, A., Bonfoh, B. and Kati-Coulibaly, S. 2014. Sensory Evaluation of green tea from Lippia multiflora Moldenke leaves. European Scientific Journal. 10(3):536-545.

[5] Carlin, E., Contar, D.P. and Silva-Filho, J. 1986. Pharmacology of lemon grass (Cymbopogon Stapf): Effects of teas prepared from leaves on laboratory animals. Journal of Ethnophamacology.17(1):37-64.

[6] Nambiar, V.S. and Matela, H. 2012. Potential Functions of Lemon Grass (Cymbopogon) in Health and Disease.International Journal of Pharmaceutical \& Biological Archives. 3(5):1035-1043.

[7] Srivastava, V., Dubey, S. and Mishra, A. 2013. Areview on Lemongrass: Agricultural and Medicinal Aspect. International Research Journal of Pharmacy. 4(8):42-44.

[8] Olorunnisola, S.K., Asiyanbi, H.T., Hammed, A.M. and Simsek, S. 2014. Biological properties of lemongrass: An overview. International Food Research Journal. 21(2):455-462.

[9] Peters, U., Charles, P. and Lenore, A. 2001. Does Tea Affect Cardiovascular Disease? A Meta-Analysis.American Journal of Epidemiology. 154(6):495-503.

[10] Rietveld, A. and Wiseman, S. 2003. Antioxidant Effects of Tea Evidence from Human Clinical Trials. American Society for Nutritional Sciences. Proceedings of the Third International Scientific Symposium on Tea and Human Health: Role of Flavonoids in the Diet. Pages 3285-3292.

[11] Pooley, E. 1998. A field guide to wild flowers: Kwazulu-Natal and the Eastern region, Durban: Natal Flora Publications Trust.Durban. Pages 420 - 421.

[12] Pascual, E., Slowing, K., Carretero, E., Sánchez-Mata, D., and Villar, A. 2001. Lippia: traditional uses, chemistry and pharmacology: a review. Journal of Ethnopharmacology. 76:201-214.

[13] Benoît-Vical, F., Valentin, A., Pelissier, Y., Marion, C., Milhan, M., Maillie, M., Bastide, J. M., Diafouka, F., Kone, B. D., Malan, A., Kone, M., Loukou, Y., Monet D., Ake, A. and Yapo,
A. 1996. Confirmation in vitro de l'activité antimalarique de certaines plantes d'origine Africaine utilisées en medicine traditionnelle. Médecine d'Afrique noire.43(7): 393-400.

[14] Sanodiya, B.S., Thakur, G.S., Baghel, R.K., Prasad, G.B. and Bisen, P.S. 2009. Ganoderma lucidum: a potent pharmacological macrofungus. Curr Pharm Biotechnol. 10(8):717-742.

[15] Chen, N.H., Liu, J.W. and Zhong, J.J. 2010. Ganoderic acid T inhibits tumor invasion in vitro and in vivo through inhibition of MMP expression. Pharmacological reports: PR.62(1):150-163.

[16] Smina, T.P., Mathew, J., Janardhanan, K.K., Devasagayam, T.P. 2011. Antioxidant activity and toxicity profile of total triterpenes isolated from Ganoderma lucidum (Fr.) P. Karst occurring in South India. Environmental Toxicology and Pharmacology. 32(3):438-446.

[17] Hanaoka, R., Ueno, Y., Tanaka, S., Nagai, K., Onitake, T., Yoshioka, K. and Chayama, K.2011. The water-soluble extract from cultured medium of Ganoderma lucidum (Reishi) mycelia (Designated as MAK) ameliorates murine colitis induced by trinitrobenzene sulphonic acid. Scandinavian Journal of Immunology. 74(5):454-462.

[18] Chui, H., Wong, S., Cheng, Y., Lau, Y., Kok, H., Cheng, H., Cheung, F., Tang, K., Teo, T., Chan, S., et al. 2002. Antiproliferative ability of a combination regimen of crocodile egg extract, wild radix ginseng and natural Ganoderma lucidum on acute myelogenous leukemia. Oncology Report.16:1313-1316.

[19] AOAC. 2005. Official Method of Analysis (18 ${ }^{\text {th }}$ Ed.). Association of Official Analytical Chemists International, Maryland, USA.

[20] Dzah, C.S. 2014. Influence of fruit maturity on antioxidant potential andchilling injury resistance of peach fruit (Prunus persica)during cold storage. African Journal of Food, Agriculture, Nutrition and Development. 14(7):9578-9591.

[21] Martinez, M.N. and Amidon,G.L. 2002. A Mechanistic Approach to Understanding the Factors Affecting Drug Absorption: A Review of Fundamentals. Journal of Clinical Pharmacology. 42:620-643.

[22] Chin, S.K., Law, C.L. and Cheng, P.G. 2011. Effect of drying on crude ganoderic acids and water soluble polysaccharides content in Ganoderma lucidum. International Journal of Pharmacy and Pharmaceutical Sciences. 3(1):38-43.

[23] Ekissi, A.C., Yao-Kouame, A., Konan, A.G., Alui, K.A., Agbo, N.G. and Kati-Coulibaly, S. 2013. Manufacturing Process and Various uses of Savannah Herbal Tea (Lippia multiflora) in Côte d'Ivoire. Asian Journal of Agriculture and Rural Development. 3(8):597-608.

[24] Khan, M.A., Khan, L.A., Hossain, M.S., Tania, M. and Uddin, M.N. 2009. Investigation on the Nutritional Composition of Common Edible and Medicinal Mushrooms Cultivated in Bangladesh. Bangladesh Journal of Mushroom. 3(1): 21-28.

[25] Ekissi, A.C., Konan, A.G., Yao-Kouame, A., Bonfoh, B. and Kati-Coulibaly, S. 2011. Evaluation of the chemical constituents of savannah tea (Lippia multiflora) leaves. Journal of Applied Biosciences. 42:2854-2858. 
[26] St. Jeor, S.T., Howard, B.V., Prewitt, E., Bovee, V., Bazzarre, T. and Eckel, R.H. 2001. A statement for healthcare professionals from the nutrition committee of the council on nutrition, physical activity, and metabolism of the American Heart Association. Circulation 104:1869-1874.

[27] Pêcher, C., Pécourt, A., Noël, A.-R., Dacremont, C. and Valentin, D. 2012. Identifying drivers of consumers' choice to develop new cooking devices. In: Valentin D, Pêcher C, Nguyen DH, Chambers D and Abdi H (eds). Integrating sensory evaluation into product development: An Asian perspective. Proceedings of SPISE-Summer Program in Sensory Evaluation. 3rd International Symposium, Vietnam.

[28] Petravić, T.V., Kovačević, G.K., Komes, D., Gracin, L., Banović, M. and Marić, V. 2008.Influence of media composition and temperature on volatile aroma production by various wine yeaststrains. Czech Journal of Food Science. 26:376-382.

[29] Dagupen, M.K., Januszewska, R., Lino, L.L., Tagarino, D., Viaene, J., Arguelles, R. and Bautista, R. 2009. Consumer behavior towards lemongrass (Cymbopogon) tea in Benguet Province, Northern Philippines. BANWA. 6(2):1-12.

[30] De-Heer, N.E.A., Twumasi, P., Tandoh, M.A., Ankar-Brewoo, G.and Oduro, I. 2013. Formulation and sensory evaluation of herb tea from Moringa oleifera, Hibiscus sabdariffa and Cymbopogon. Journal of the Ghana Science Association. 15(1):53-62.

[31] Nishitoba, T., Sato, H., Kasai, T., Kawagishi, H. and Sakamura, S. 1985. New bitter $\mathrm{C}_{27}$ and $\mathrm{C}_{30}$ terpenoids from the fungus Ganoderma lucidum. Agric. Boil. Chem. 49:17931798.
[32] Liu, X., Yuana, J.-P. and Chen, X.-J. 2002. Antitumor activity of the sporoderm-broken germinating spores of Ganoderma lucidum. Cancer Letters. 182:155-161.

[33] Moors, E.H. 2012. Functional foods: regulation and innovations in the EU. Innovation: The European Journal of Social Science Research. 25(4):424-440.

[34] Asthana, A., Larson, R.A., Marley, K.A. and Tuveson, R.W. 1992. Mechanisms of citral phototoxicity. Phytochemistry and Photobiology. 56:211-222.

[35] Khwaja, S., Hussain, A., Hussain, H. and Faiyazuddin, M. 2013. Insight to lemongrass essential oil as phytomedicine: state of the art and future perspectives. Asian Journal of Phytomedicine and Clinical Research.2(3):87 - 96.

[36] Yao-Kouame, A. and Kane, F. 2008. Biochemical Characteristics of Lippia multifora (Verbenaceae) Leaves with Respect to Fertilizer Applied to the Soil. Journal of Plant Sciences.3: 287-291.

[37] Juliani, H.R., Wang, M., Moharram, H., Asante-Dartey, J., Acquaye, D., Koroch, A.R. and Simon, J.E. 2006. Intraspecific Variation in Quality Control Parameters, Polyphenol Profile, and Antioxidant Activity in Wild Populations of Lippia multiflora from Ghana. In Herbs: Challenges in Chemistry and Biology pp 126-142, American Chemical Society Press.

[38] Agarwal, K., Chakarborthy, G.S. and Verma, S. 2012. In vitro antioxidant activity of different extract of Ganoderma lucidum. DHR International Journal of Pharmaceutical Sciences. 3(1):48-54. 